
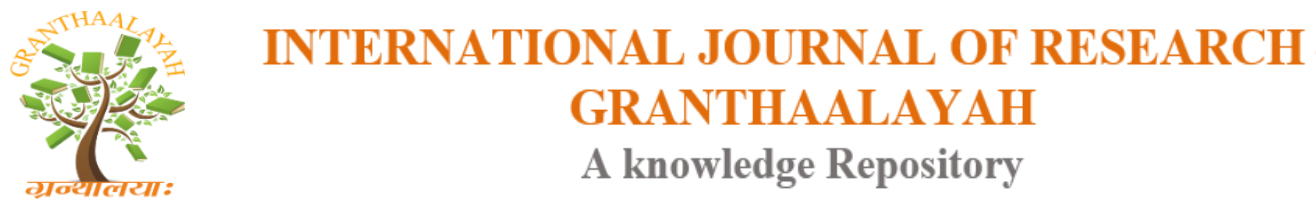

DOI: 10.29121/granthaalayah.v6.i4.2018.1637

Science

\title{
GEOCHEMICAL FACIES OF THE TURONIAN GONGILA FORMATION, BORNU (CHAD) BASIN, NIGERIA: IMPLICATION FOR PROVENANCE, PALEOCLIMATE AND PALEOWEATHERING CONDITIONS
}

\author{
B. Shettima 1, F. D. Adams 1, A. I. Haruna ${ }^{2}$, A. I. Goro ${ }^{3}$, M. Bukar ${ }^{1}$ \\ ${ }^{1}$ Department of Geology, University of Maiduguri, Nigeria \\ ${ }^{2}$ Department of Applied Geology, ATBU Bauchi, Nigeria \\ ${ }^{3}$ Department of Geology, Federal University of Technology Minna, Nigeria
}

\begin{abstract}
Geochemical evaluation of the Gongila Formation of Bornu (Chad) Basin indicated mineralogical compositions of quartz, feldspar, anatase, gypsum, smectite and kaolinite from XRD analysis. Corresponding major oxides from XRF analysis indicated the dominance of $\mathrm{SiO} 2$ with an average of 54.91 wt $\%$ followed by $\mathrm{A} 12 \mathrm{O} 3$ with 15.92 wt $\%$. $\mathrm{CaO}, \mathrm{NaO}, \mathrm{K} 2 \mathrm{O}, \mathrm{MgO}, \mathrm{MnO}, \mathrm{Fe} 2 \mathrm{O} 3 \mathrm{TiO} 2$ and P2O5 occurred with average compositions of $1.87 \%, 1.02 \%, 2.15 \%, 1.17 \%, 0.06 \%, 3.04 \%$, $0.03 \%$ and $1.52 \%$ respectively. Alteration indexes derivations from these oxides consisting of Chemical Index of Alteration (CIA), Plagioclase Index of Alteration (PIA) and Chemical Index of Weathering (CIW) accounted for a dominantly moderate weathering condition for the formation. Discriminant plots of $\mathrm{Fe} 2 \mathrm{O} 3+\mathrm{MgO}$ versus $\mathrm{TiO} 2$ indicated a tectonically passive source area composed of generally intermediate igneous rocks, affirmed by $\mathrm{Al} 2 \mathrm{O} 3$ versus $\mathrm{TiO} 2$ bivariate model with skewed plot along the granite line. The dominance of smectite suggests prevalence of arid to semi-arid paleoclimatic conditions during the deposition of shales of the Gongila Formation. Intermittent phases of superposed tropical climate are also depicted by the subordinate kaolinite mineralization.
\end{abstract}

Keywords: Chad Basin; Geochemistry; Mineralogy; Gongila Formation.

Cite This Article: B. Shettima, F. D. Adams, A. I. Haruna, A. I. Goro, and M. Bukar. (2018). "GEOCHEMICAL FACIES OF THE TURONIAN GONGILA FORMATION, BORNU (CHAD) BASIN, NIGERIA: IMPLICATION FOR PROVENANCE, PALEOCLIMATE AND PALEOWEATHERING CONDITIONS." International Journal of Research - Granthaalayah, 6(4), 144-156. https://doi.org/10.5281/zenodo.1242621.

\section{Introduction}

Physical and chemical alteration of pre-existing rocks, precursory to sedimentary evolution preserves relicts of these conditions within the emerging geochemical species, thus hosting vital signatures on weathering conditions, provenance, sediment recycling and regional tectonics [1-2]. Shales constitute over $65 \%$ of the entire global sedimentary sequences and because of its relative 
preferential enrichment of trace elements, it is considered to represent average composition of the upper continental crust [3]. Therefore, they present an indispensable tool in retracing and reconstruction of not only provenance, but also source rock composition, because of their restricted redistribution during sedimentation, lithogenesis and metamorphism [4-5]. Mineralogical assemblage and abundance in these shales are as well a function of the paleoenvironmental conditions, hence, their associations and suites are reliable indexes to paleoclimate, weathering and tectonics operating within a sedimentary basin [6-7]. The Gongila Formation in the Bornu (Chad) Basin composes of thick sequences of shales and limestones deposits of a shallow marine setting [8-9]. This Turonian shale sequences account for the full marine inundation of the basin and represent the global mid - Cretaceous transgressive event. Its outcrops are generally restricted to the southeastern part of the basin, where it is found well exposed at Mutai village (Fig.1). This research was carried out at this locality with the aim of determining the provenance of these shales, as well as paleoweathering and paleoclimatic conditions characterizing the Turonian of the Bornu (Chad) Basin.

\section{Geological and Statigraphic Setting}

The Bornu Basin is part of the West African intracratonic basin located in northeastern part Nigeria and originated as a consequence of an active phase of sea floor spreading in the Atlantic during the mid-Cretaceous that led to the separation of the African and South American plates [10-11]. The accompanying subsidence in these basins lead to widespread marine transgression and regression regimes building out sequences of marine and continental deposits [8]. The Albian sediments composing of a continental, sparsely-fossiliferous medium to coarse grained feldspathic sandstone with shale intercalations of the Bima Sandstone records the inception of sedimentation in the Bornu Basin (Fig. 2). This formation rests directly on the Precambrian Basement Complex $[8,12,13]$. The Gongila Formation conformably follows this continental unit and it is typically composed of calcareous shale and limestone deposited in shallow marine environment [14]. (Fig. 3). The deposition of this formation marks the beginning of marine incursion into the Bornu Basin [8]. The marine transgression which started in the Cenomanian reveals its peak in the Turonian during which the bluish-black, ammonites-rich open marine Fika Shale was deposited, and this

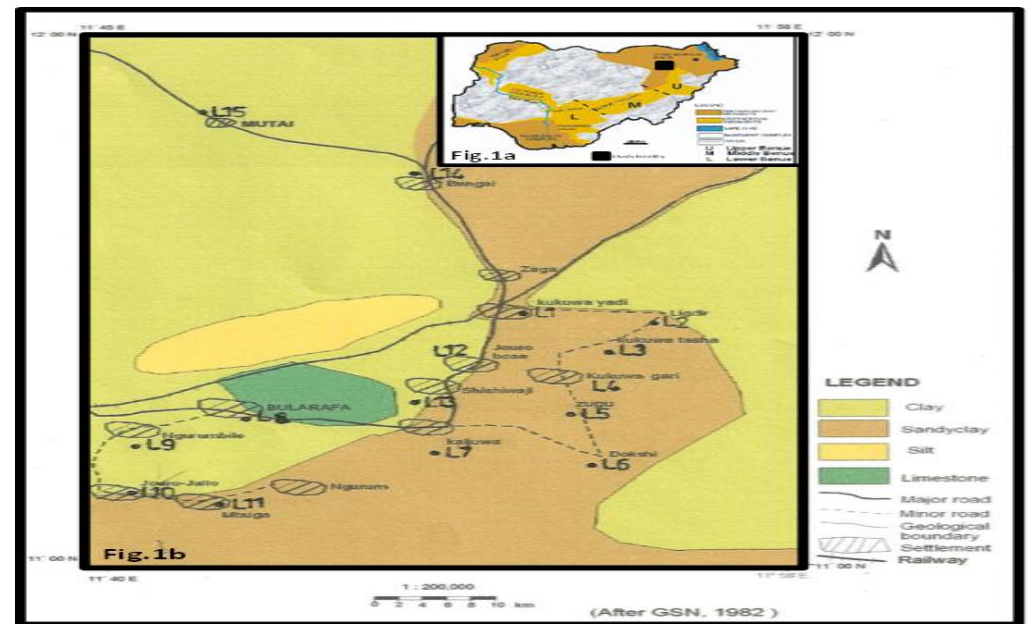

Figure 1(a): Geological map of Nigeris showing study location (b) geological map of the Mutai area showing sample locations 


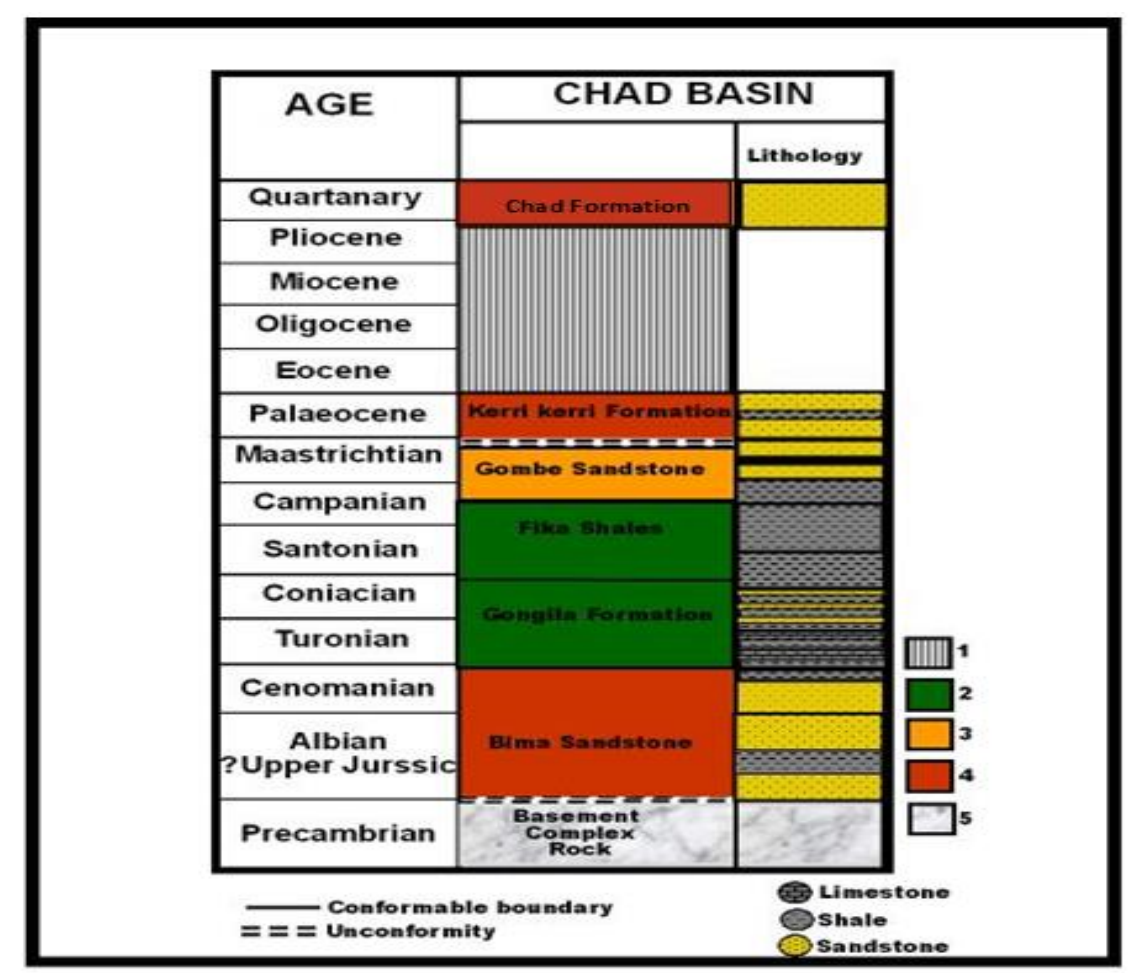

Figure 2: Stratigraphic succession of the Bornu Basin [8] 1-Hiatus, 2-marine sediments, 3Transitional sediments, 4-continental sediments, 5-basement complex

Deposition continued into the Santonian [8]. The Gombe Sandstone which contains intercalation of siltstone, shale, ironstone and sandstone was deposited in the Maastrichtian unconformably overlying the Fika Shale.

In the Late Maastrichtian times and up to the end of the Cretaceous a phase of extensional deformation occurred in the Bornu Basin. This resulted in reconstructing an elongate NE-SW graben system in the basin. The deformation formed a new depo-center where Paleoene deposits of the Kerri-Kerri Formation accumulated unconformably on the Cretaceous sediments [8, 15]. In the Pleistocene and presumably during the Pliocene, the continental deposits of the Chad Formation were unconformably deposited above the Kerri-Kerri Formation $[8,16]$. Toward the end of the Tertiary to recent times, widespread volcanic activities occurred in the south and central part of the basin.

\section{Methodology}

The study was conducted around Mutai village and environs, falling into sheet 110 of the Federal Survey Map of Nigeria (Fig.1b). A total of fifteen (15) samples claystones were collected for geochemical analyses, out of which ten (10) were further subjected to mineralogical studies. Major element analyses were carried out for clay samples using Inductively Couple Plasma- Optical Emission Spectrometry (ICP-OES) and X-Ray Fluorescence (XRF). ICP-OES (Optimal 2000DV) was used to analyze for $\mathrm{K}, \mathrm{Al}, \mathrm{Ca} \mathrm{Mg}, \mathrm{Fe}, \mathrm{Mn}$, Ti, and P. For the ICP-OES analysis, the samples were at first ashed and $0.2 \mathrm{~g}$ of each was digested using concentrated nitric acid (HNO3) and concentrated Hydrochloric acid $(\mathrm{HCl})$. The samples were then introduced into the ICP-OES as 
liquid medium and nebulized as aerosol. The aerosol is dissolved, vaporized and atomized, then excited and ionized in order to obtain characteristic atomic radiation from where the elements and their concentration were recorded. In the XRF analysis, $\mathrm{SiO} 2$ and $\mathrm{AlO} 3$ were determined. Five gramme $(5 \mathrm{~g})$ of the pulverized samples were introduced into the X-Ray chamber of the minimate (PanAnalytical) XRF machine. The machine was calibrated and run having the results presented in the "result window" of the attached computer in weight percentage oxide (wt $\%$ oxide). The lost on ignition (LOI) was determined using Carbolite furnace. One gramme (1g) of the sieved samples of claystones were transferred to crucibles and placed into a furnace that was set to 10000C for about one and a half hours. The samples were left in the furnace to cool, after which they were reweighed to determine the LOI. Clay mineralogical analysis was carried out on $2 \mu \mathrm{m}$ clay - size fraction of 5 mudstone samples based on unoreinted X-ray powder diffractiometry (XRD) technique. X-ray identification of the clay fractionation was performed at University of Liverpool using Panalytical X pert pro MPD X-ray Diffractometer (2008) with reference patterns from international centre for diffraction data, powder Diffraction file 2 release in 2008. Equipment is set with $\mathrm{CuK} \alpha$ radiation of $40 \mathrm{kv}$ and $40 \mathrm{~mA}$, Co Filters and scan range of $5-60 \mathrm{o} 2 \Theta$.

\section{Results}

\section{Mineralogy}

The mineralogical analysis of the claystone samples of the Gongila Formation at Bularafa, Zugu, Ligdir, Gurumbile, Jouro-Jallo, Shishiwaji, Jouro-Bose, Kukuwa-Tasha, Kukuwa-Yadi and Kukuwa Gari villages indicated the occurrence of smectite and kaolinite clay mineral species. Smectite ranges from 6 to $28 \mathrm{wt} \%$ with average of $15.70 \mathrm{wt} \%$, whereas kaolinite ranges from 6 to $13 \mathrm{wt} \%$ with an average of $8.20 \mathrm{wt} \%$ (Table 1). Gypsum is present in samples from KukuwaTasha and Kukuwa-Yadi and range between $1 \mathrm{wt} \%$ to $11 \mathrm{wt} \%$ with an average of $2.10 \mathrm{wt} \%$. Anatase were recorded only at Zugu and Bularafa village, with concentration of about only $1 \mathrm{wt} \%$. Other non-clay minerals identified are quartz which ranges from $30 \mathrm{wt} \%$ at Zugu to $72 \mathrm{wt} \%$ at Ligdir with an average of $50.30 \mathrm{wt} \%$. Plagioclase feldspar varies from $6 \mathrm{wt} \%$ at Kukuwa Tasha and Kukuwa Gari to 9 wt\% at Shishiwaji and Zugu, with an average of 4.5 wt \% (Table 1). The minerals are identified in the diffractographs (Fig.3).

\section{Geochemistry}

Chemical analyses carried out on clay samples of the Gongila Formation shows that $\mathrm{SiO} 2$ and $\mathrm{A} 12 \mathrm{O} 3$ are the major oxides with highest concentrations in the samples analysed. The $\mathrm{SiO} 2$ content ranges from $51.80 \mathrm{wt} \%$ to $61.22 \mathrm{wt} \%$ averaging $54.91 \mathrm{wt} \%$ while $\mathrm{Al} 2 \mathrm{O} 3$ varies from $12.30 \mathrm{wt}$ $\%$ to $20.61 \mathrm{wt} \%$ with an average of $15.92 \mathrm{wt} \%$ (Table 2). The $\mathrm{CaO}$ varies between $1.11 \mathrm{wt} \%$ to $2.9 \mathrm{wt} \%$ and averages $1.87 \mathrm{wt} \%$. Na2O concentration ranged from $0.42 \mathrm{wt} \%$ to $1.45 \mathrm{wt} \%$ with an average of $1.02 \mathrm{wt} \%$ while $\mathrm{K} 2 \mathrm{O}(\mathrm{K} 2 \mathrm{O})$ ranges from $0.34 \mathrm{wt} \%$ to $4.51 \mathrm{wt} \%$, averaging 2.15 wt $\% . \mathrm{MgO}$ and $\mathrm{MnO}$ range from $1.06 \mathrm{wt} \%$ to $1.3 \mathrm{wt} \%$ and $0.01 \mathrm{wt} \%$ to $0.13 \mathrm{wt} \%$ respectively with averages of $1.17 \mathrm{wt} \%$ and $0.06 \mathrm{wt} \%$ respectively. Ferric oxide (Fe2O3) content ranged from $0.69 \mathrm{wt} \%$ to $5.25 \mathrm{wt} \%$ averaging $3.04 \mathrm{wt} \%$. TiO2 ranges from $0.001 \mathrm{wt} \%$ to $0.09 \mathrm{wt} \%$ with an average of $0.03 \mathrm{wt} \%$. Phosporous pentaoxide (P2O5) content ranges from $0.14 \mathrm{wt} \%$ to $3.86 \mathrm{wt}$ $\%$ with an average of $1.52 \mathrm{wt} \%$. The Loss On Ignition (LOI) ranges from $6.0 \%$ to $16.0 \%$ with an average of $11.46 \%$ (Table 2). Major oxide correlation coefficient analysis indicated a strong negative correlation between $\mathrm{SiO} 2$ and $\mathrm{Al} 2 \mathrm{O} 3(\mathrm{r}=-0.53)$, pointing to a dominance of clays and 
micas in the mudstones of the Gongila Formation and corresponding dilution and depletion of $\mathrm{SiO} 2$ (e.g. Kanpunzu et al., 2005). This dominance is

Table 1: Average composition of the minerals (wt. \%) in Mutai area

\begin{tabular}{|c|c|c|c|c|c|c|c|c|c|c|c|}
\hline Location & $\begin{array}{c}\text { Kukawa } \\
\text { Yadi (L1) }\end{array}$ & $\begin{array}{l}\text { Ligdir } \\
\text { ( L2) }\end{array}$ & $\begin{array}{c}\text { Kukawa } \\
\text { Tasha } \\
\text { (L3) }\end{array}$ & $\begin{array}{c}\text { Kukawa } \\
\text { Gari (L4) }\end{array}$ & $\begin{array}{c}\text { Zugu } \\
\text { (L5) }\end{array}$ & $\begin{array}{c}\text { Bulara } \\
\text { (L8) }\end{array}$ & $\begin{array}{c}\text { Ngurumbile } \\
\text { (L9) }\end{array}$ & $\begin{array}{c}\text { Jauro Jallo } \\
(\mathrm{L} 10)\end{array}$ & $\begin{array}{l}\text { Jauro } \\
\text { Bose } \\
(\mathrm{L} 12) \\
\end{array}$ & $\begin{array}{c}\text { Shishiwaji } \\
\text { (L13) }\end{array}$ & $\begin{array}{c}\text { Average } \\
\text { Weight } \\
(\%)\end{array}$ \\
\hline Quartz & 40 & 72 & 54 & 53 & 30 & 41 & 36 & 70 & 55 & 49 & 50.3 \\
\hline Anatase & ND & ND & ND & ND & 1 & 1 & ND & trace & trace & ND & 0.2 \\
\hline Plagioclas & ND & ND & 6 & 6 & 9 & 7 & 8 & trace & ND & 9 & 4.5 \\
\hline K-feldspa & 13 & 16 & 22 & 24 & 21 & 22 & 27 & 10 & 11 & 24 & 19 \\
\hline Kaolinite & 6 & 6 & 6 & 6 & 12 & 11 & 13 & 8 & 8 & 6 & 8.2 \\
\hline Smectite & 18 & 6 & 11 & 11 & 21 & 18 & 16 & 12 & 23 & 11 & 15.7 \\
\hline Gypsum & 11 & ND & 1 & ND & 6 & ND & ND & ND & 3 & ND & 2.1 \\
\hline
\end{tabular}

Further buttressed by the positive correlation of $\mathrm{A} 12 \mathrm{O} 3$ with $\mathrm{K} 2 \mathrm{O}(\mathrm{r}=0.27)$, indicating a source from k-bearing minerals (k-feldpars, muscovite and biotite). This inference is also supported by the relatively high ratio of $\mathrm{K} 2 \mathrm{O} / \mathrm{Na} 2 \mathrm{O}$ that ranges from $0.31-4.50$ indicative of the presences of $\mathrm{k}$ - bearing minerals. $\mathrm{SiO} 2$ also showed a weak negative correlation with Fe2O3 and P2O5 (r=0.1 and
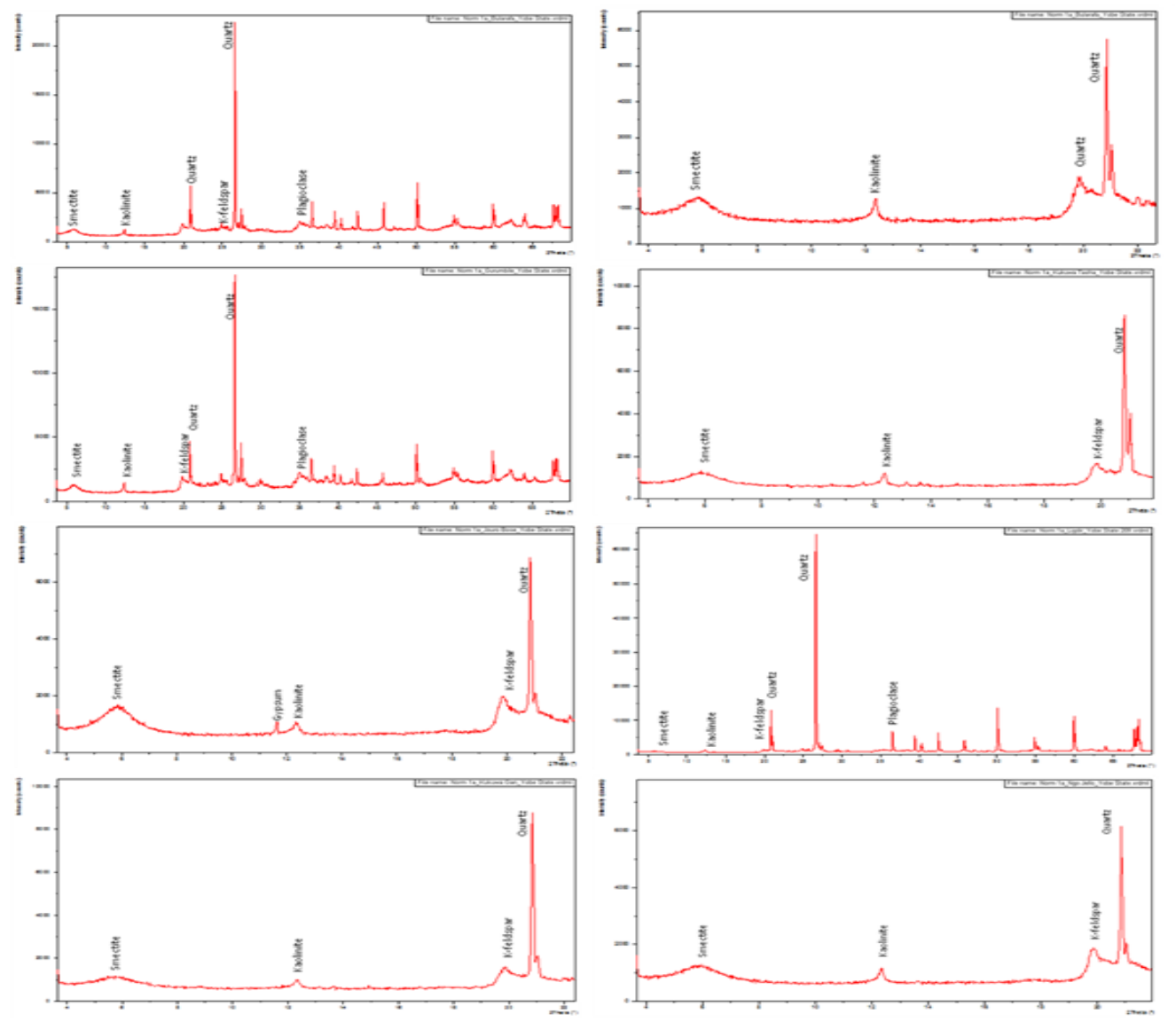

Figure 3: XRD Difractographs of shales of the Gongola Formation 
-0.06 respectively) and weak positive correlation with $\mathrm{K} 2 \mathrm{O}, \mathrm{Na} 2 \mathrm{O}, \mathrm{CaO}, \mathrm{MgO}, \mathrm{MnO}$ and $\mathrm{TiO} 2$ $(r=0.2,0.12,0.01,0.16,0.17$ and 0.25 respectively) (Fig.4). This accounts for contributions

Table 2: Showing weight percentage of major oxides

\begin{tabular}{|c|c|c|c|c|c|c|c|c|c|c|c|c|}
\hline \multirow{2}{*}{\multicolumn{3}{|c|}{$\begin{array}{c}\text { Major Oxides Ligdir } \\
\text { Kukawa Gari } \\
\text { Ngurumb } \\
\end{array}$}} & \multirow{2}{*}{$\begin{array}{l}\text { Ngo-jal } \\
\text { Mutai } \\
\text { Mbuga }\end{array}$} & \multicolumn{3}{|c|}{ Jauro Bose } & \multicolumn{4}{|c|}{ Kukawa TashaBularafa } & \multirow{2}{*}{\multicolumn{2}{|c|}{$\begin{array}{l}\text { Bungai Dokshi } \\
\text { Zugu }\end{array}$}} \\
\hline & & & & \multicolumn{2}{|c|}{ Shishiwaji } & \multicolumn{2}{|c|}{ Kaljiwa } & \multicolumn{3}{|c|}{ Kuykawa Yadi } & & \\
\hline $\mathrm{SiO} 2$ & $\begin{array}{l}53.21 \\
53.42\end{array}$ & $\begin{array}{l}51.8 \\
58.1\end{array}$ & $\begin{array}{l}54.42 \\
58.47\end{array}$ & 52.46 & 57.41 & 45.42 & 56.73 & 56.44 & 54.6 & 61.22 & 53.79 & 56.1 \\
\hline $\mathrm{A} 12 \mathrm{O} 3$ & $\begin{array}{l}17.21 \\
18.21\end{array}$ & $\begin{array}{l}17.4 \\
13.42\end{array}$ & $\begin{array}{l}13.33 \\
13.42\end{array}$ & 20.61 & 19 & 18.4 & 11.3 & 16.7 & 18 & 14.21 & 15.3 & 12.3 \\
\hline $\mathrm{CaO}$ & $\begin{array}{l}1.11 \\
1.83\end{array}$ & $\begin{array}{l}1.93 \\
2.7\end{array}$ & $\begin{array}{l}1.76 \\
2.9\end{array}$ & 2.01 & 2.08 & 1.6 & 1.43 & 1.27 & 1.49 & 1.43 & 2.5 & 1.95 \\
\hline $\mathrm{Na} 2 \mathrm{O}$ & $\begin{array}{l}0.96 \\
1.09\end{array}$ & $\begin{array}{l}0.99 \\
0.96\end{array}$ & $\begin{array}{l}0.84 \\
1.15\end{array}$ & 1.2 & 1.35 & 0.8 & 1.45 & 0.42 & 0.95 & 0.86 & 1.25 & 1.09 \\
\hline $\mathrm{K} 2 \mathrm{O}$ & $\begin{array}{l}1.11 \\
3.63\end{array}$ & $\begin{array}{l}3.17 \\
4.51\end{array}$ & $\begin{array}{l}1.54 \\
2.74\end{array}$ & 2.66 & 3.97 & 2.11 & 1.82 & 0.87 & 1.49 & 1.34 & 2 & 0.34 \\
\hline $\mathrm{MgO}$ & $\begin{array}{l}1.06 \\
1.17\end{array}$ & $\begin{array}{l}1.15 \\
1.3\end{array}$ & $\begin{array}{l}1.15 \\
1.11\end{array}$ & 1.17 & 1.27 & 1.11 & 1.18 & 1.18 & 1.07 & 1.08 & 1.3 & 1.17 \\
\hline $\mathrm{Fe} 2 \mathrm{O} 3$ & $\begin{array}{l}0.69 \\
4.4\end{array}$ & $\begin{array}{l}3.82 \\
3.95\end{array}$ & $\begin{array}{l}3.88 \\
2.46\end{array}$ & 2.99 & 5.25 & 3.14 & 3.71 & 1.7 & 1.9 & 1.16 & 3.07 & 3.4 \\
\hline $\mathrm{MnO}$ & $\begin{array}{l}0.01 \\
0.07\end{array}$ & $\begin{array}{l}0.09 \\
0.2\end{array}$ & $\begin{array}{l}0.06 \\
0.04\end{array}$ & 0.08 & 0.13 & 0.03 & 0.02 & 0.02 & 0 & 0.03 & 0.08 & 0.07 \\
\hline $\mathrm{TiO} 2$ & $\begin{array}{l}0.02 \\
0.01\end{array}$ & $\begin{array}{l}0.001 \\
0.24\end{array}$ & $\begin{array}{l}0.02 \\
0.02 \\
\end{array}$ & 0.01 & 0.004 & 0.001 & 0.003 & 0.086 & 0.009 & 0.001 & 0.071 & 0.003 \\
\hline $\mathrm{P} 2 \mathrm{O} 5$ & $\begin{array}{l}0.88 \\
0.75\end{array}$ & $\begin{array}{l}1.93 \\
3.86\end{array}$ & $\begin{array}{l}2.04 \\
0.14\end{array}$ & 2.23 & 2.45 & 1.54 & 1 & 1.06 & 1.2 & 0.7 & 1.37 & 1.71 \\
\hline LOI & $\begin{array}{l}13.17 \\
10\end{array}$ & $\begin{array}{l}12.44 \\
6\end{array}$ & $\begin{array}{l}10.21 \\
10\end{array}$ & 7.91 & 11.46 & 16 & 15.42 & 12 & 13.9 & 11 & 10 & 11.42 \\
\hline $\mathrm{K} 2 \mathrm{O} / \mathrm{A}$ & $\begin{array}{c}12 \mathrm{O} 3 \\
0.03\end{array}$ & $\begin{array}{l}0.06 \\
0.20\end{array}$ & $\begin{array}{l}0.18 \\
0.34\end{array}$ & $\begin{array}{l}0.12 \\
0.20\end{array}$ & 0.13 & 0.21 & 0.11 & 0.16 & 0.05 & 0.08 & 0.09 & 0.13 \\
\hline CIA & $\begin{array}{l}84.4 \\
73.6\end{array}$ & $\begin{array}{l}74.1 \\
62.2\end{array}$ & $\begin{array}{l}76.3 \\
66.4\end{array}$ & 77.8 & 71.9 & 80.3 & 70.6 & 86.7 & 82.1 & 79.7 & 72.7 & 78.4 \\
\hline PIA & $\begin{array}{l}88.6 \\
83.3 \\
\end{array}$ & $\begin{array}{l}82.9 \\
70.9 \\
\end{array}$ & $\begin{array}{l}81.9 \\
72.5 \\
\end{array}$ & 84.8 & 81.4 & 87.2 & 76.7 & 90.4 & 87.1 & 84.9 & 78 & 70.7 \\
\hline CIW & $\begin{array}{l}89.3 \\
86.2\end{array}$ & $\begin{array}{l}85.6 \\
78.6\end{array}$ & $\begin{array}{l}83.7 \\
76.8\end{array}$ & 86.5 & 87.2 & 88.5 & 79.7 & 90.8 & 88.1 & 86.1 & 80.3 & 80.2 \\
\hline
\end{tabular}




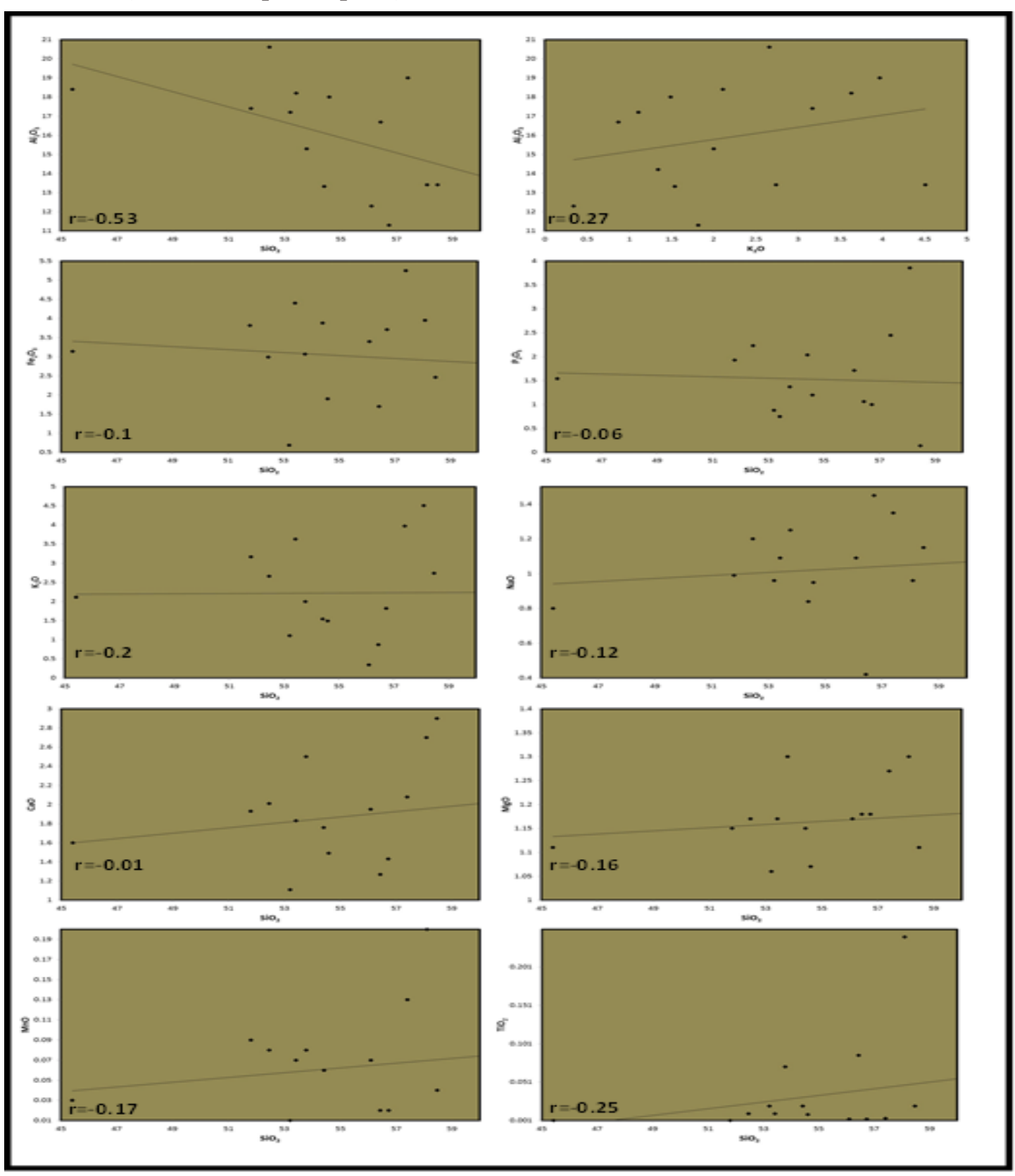

Figure 4: Correlation coefficient plots for $\mathrm{SiO} 2$ against major oxides

From clay minerals. However, the negative correlation of $\mathrm{TiO} 2$ with $\mathrm{Al} 2 \mathrm{O} 3(\mathrm{r}=-0.53)$ and its positive correlation with $\mathrm{MgO}, \mathrm{K} 2 \mathrm{O}, \mathrm{Fe} 2 \mathrm{O} 3$ and $\mathrm{CaO}(0.59,0.38,0.073$ and 0.43$)$ may also account for derivative from mafic minerals (Fig.5a-e). More so, its low concentration (av. 0.01) points to presence of phyllosilicate, but in relatively small concentrations [17]. The TiO2 is generally immobile during sedimentary dynamic process making it a powerful tool in provenance analysis. Its dominantly low values in the mudstones of the Gongila Formation commonly below the PAAS suggest abundances of felsic materials in the provenances area (Table 2). P2O5 values are commonly higher than the PAAS, this may account for high contribution from accessory minerals as apatite and monzonite. $\mathrm{K} 2 \mathrm{O} / \mathrm{A} 12 \mathrm{O} 3$ are 

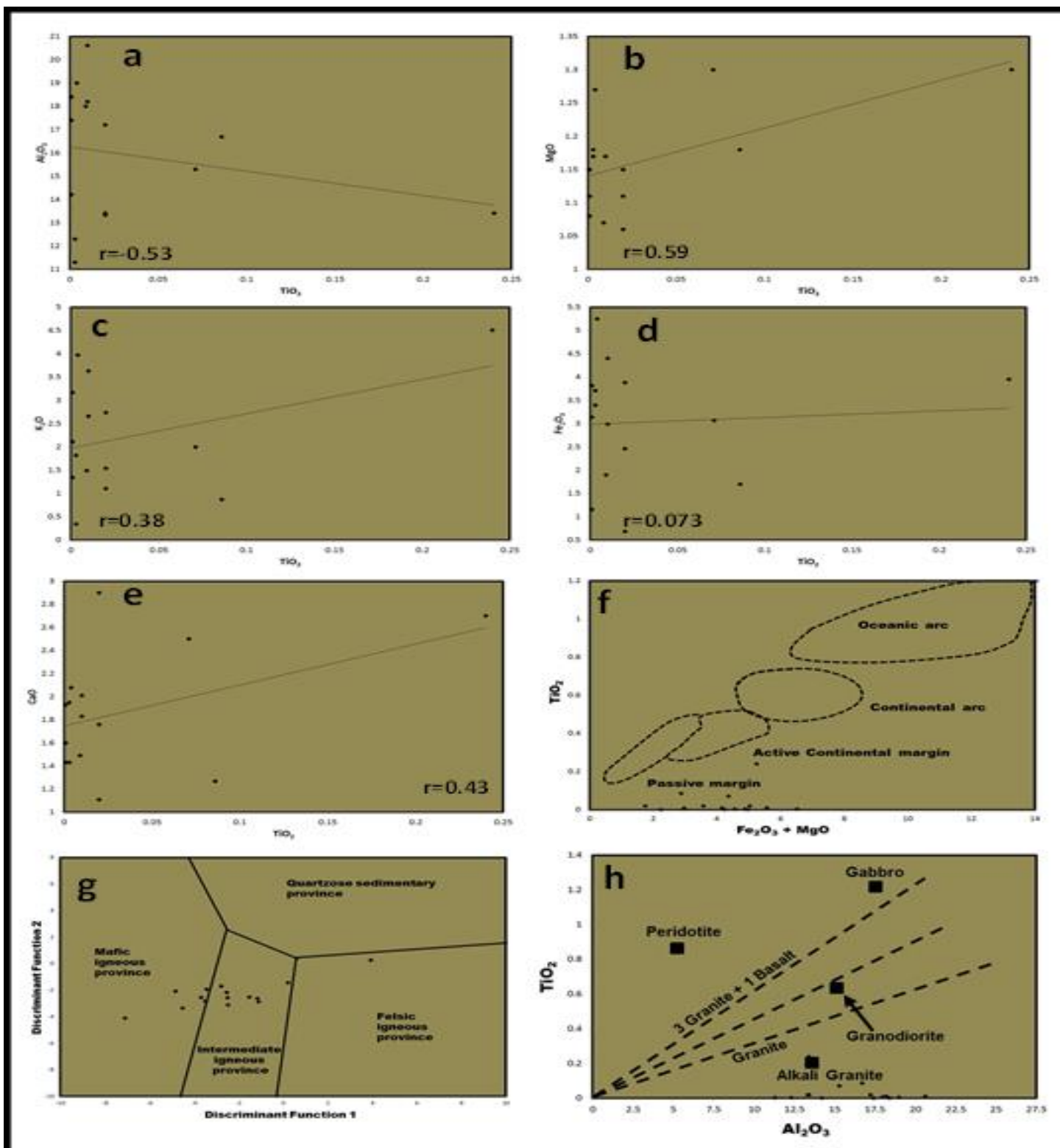

Figure 5a-e: Correlation coefficient plots for TiO2 against other major oxides, f-h) provenance models for Gongila formation

Proven indexes to original composition of ancient mudrocks, with values ranging from $0.0-0.3$ claystones and $0.3-0.9$ for feldspars [18]. A range of $0.06-0.2$ herein may suggest that contribution for the shales of the Gongila Formation are generally from claystones.

\section{Discussion}

\section{Source Rocks and Tectonic Setting}

Chemical compositions of silicilastic rocks are largely controlled by tectonic settings of provenance and as a consequence, they exhibit specific signatures with strong affinities to different tectonic provinces [19-21]. The inferences on provenance types and tectonic setting of ancient sedimentary basin are usually made from established bivariate models for geochemical species. 
The plots of $\mathrm{Fe} 2 \mathrm{O} 3+\mathrm{MgO}$ versus $\mathrm{TiO} 2$ discriminant model for shale tectonic provenance (Bhatia, 1983) indicated a skewed plot of geochemical species of the Gongila Formation around the passive margin field, which is quite consistent with earlier works on the Chad Basin that was established to have developed under passive tectonic setting [8, 12, 22] (Fig. 5f). Provenance analysis on the basis of ratio of major oxides [23] for characterizing the source material for the geochemical effluents indicated a dominant intermediate igneous provenance (Fig.5g). Mafic contributions are also notable but felsic are generally few. Considering immobile nature of $\mathrm{Al}$ and $\mathrm{Ti}$, its provenance affinity in constraining siliciclastic rocks source using $\mathrm{Al} 2 \mathrm{O} 3$ versus $\mathrm{TiO} 2$ bivariate discriminant diagram indicated a plot along the granite line for the shales of the present study (Fig.5h).

\section{Palaeoweathering}

Disintegration of rocks and the subsequent mobility of contained labile elements are preserved records of intensities of weathering in sedimentary units, thus providing an invariable tool for evaluating source area weathering conditions [28-29]. The measure of the intensities of the geochemical alterations are determined from formulated alteration indexes comprising of Chemical Index of Alteration, [28], Plagioclase Index of Alteration [26], Chemical Index of Weathering [27]. The Chemical Index of Alteration is the most widely employed in determining the degree of source area weathering of formation. This index is established on the basis of molecular proportions of major oxides in relationship where, $\mathrm{CIA}=$ $\left(\mathrm{Al} 2 \mathrm{O} 3 / \mathrm{Al} 2 \mathrm{O} 3+\mathrm{CaO}^{*}+\mathrm{Na} 2 \mathrm{O}+\mathrm{K} 2 \mathrm{O}\right) * 100$, and the $\mathrm{CaO}^{*}$ is the amount of $\mathrm{CaO}$ associated with the silicate frac $\neg$ tion of the rock. Anomalous $\mathrm{CaO}$ values are generally ignored in CIA calculation because it gives the relative proportions of secondary aluminous clay minerals to primary silicate minerals like feldspars [24]. Therefore, the method are considered in this context, where if the content of $\mathrm{CaO}$ was less or equal to that of $\mathrm{Na} 2 \mathrm{O}$ content, then we deploy the $\mathrm{CaO}$ value for further calculation, and if the $\mathrm{CaO}$ content was higher than $\mathrm{Na} 2 \mathrm{O}$, then $\mathrm{Na} 2 \mathrm{O}$ value was considered as $\mathrm{CaO}^{*}$ value [28-29]. In this present study, the shales show lower concentraרtion of $\mathrm{CaO}(1.11-$ $2.90 \%$ ), and using these values indicated moderate CIA average values (76) out of range (62 to 84 ) in the sedimentary rocks (Table 2 ). This suggest dominantly moderate intensities associated with few pulse intense chemical weathering in the source region e.g. [30-31].

CIA values herein are higher than the average NASC value of 57 [32] and slightly lower than the typical shale values [33], hence, affirming the moderate chemical weathering intensity in the source rocks. Chemical Index of Weathering (CIW) determined from molecular proportions equating $\mathrm{CIW}=\{\mathrm{Al} 2 \mathrm{O} 3 /(\mathrm{Al} 2 \mathrm{O} 3+\mathrm{CaO}+\mathrm{Na} 2 \mathrm{O})\} \times 100$ indicated values in the range of $77-91$ (av.84) (Table 2). This suggests moderate - high degree of source area weathering, largely agreeing with the findings of the Chemical Index of Alteration (CIA). The Plagioclase Index of Alteration (PIA) monitors and quantifies progressive weathering of feldspars and volcanic glass to clay minerals [26]. Therefore, it is indicative of intensity of destruction of feldspars during the course of source weathering, fluvial transport, sedimentation and diagenesis and calculated as PIA $=[(\mathrm{Al} 2 \mathrm{O} 3-\mathrm{K} 2 \mathrm{O}) /(\mathrm{Al} 2 \mathrm{O} 3+\mathrm{Na} 2 \mathrm{O}+\mathrm{CaO} *-\mathrm{K} 2 \mathrm{O})] \times 100$ (molecular proportions). The PIA values for the shales of the Gongila Formation ranged from 71 - 90 (av.82) (Table 2) indicating a dominantly moderate intensity of chemical weathering intercalated with few phases of intense conditions which are in consonance with the earlier inferences.

\section{Paleoclimate}


Bulk-rock mineralogy and clay fraction in any environmental settings are records of paleoclimatic changes and diagenetic overprint imposed through the processes of weathering and metasomatic alterations [34]. Diagensis generally obscure paleoclimatic signatures, therefore evaluation of its degree is imperative for reliable paleoenvironmental deductions. The paragenesis of detrital clay minerals records inherent complex interaction of environmental factor (temperature, pressure, Eh, $\mathrm{Ph}$, humidity etc.), synchronously operating within depositional setting, culminating in preferential evolution of mineral phase with specific climatic conditions. Under burial diagenesis, original detrital fabric and compositions are commonly transformed and changed to authegenic forms, with kaolinite altering to dickite, haloysite and nacrite morphologically and to illite chemically, while smectite evolves to chlorite [35-36]. Literarily these geochemical alterations have not been observed in this study, and coupled with the general absences of illite /smectite mixed layers, may account for a very low diagenetic overprint [37]. Furthermore, the absence of continuous variations in clay mineral content across the down dip profile of the study area are in consonance with the earlier inference, pointing to low diagenetic modulations [38]. Hence, the reliability of the clay mineral assemblage of the Gongila Formation for paleoenvironmental interpretations. The occurrence of solely smectite and kaolinite in clay mineral assemblage of this formation is indicative of a generally warm climate interchanging between hot dry and humid condition [3940], with the latter superseding because of the dominance of smectite mineralization. This mineral commonly forms in a basic medium enriched with $\mathrm{Ca}$ and $\mathrm{Na}$ under mild hydrolysis, promoted by low water - rock interaction, a common phenomenon characterizing semi-arid to arid climatic settings [41]. This condition characterizes much of the Turonian of the Bornu Basin signaling periods of low chemical weathering [42-43]. Intermittent increase in the intensity of the chemical weathering were also recorded from the relative kaolinite mineralization, depicting high rainfall favored ionic transfers and pedogenic development typically supported by humid sub - tropical to tropical climatic conditions [43].

\section{Conclusion}

The geochemical characterization of the shales of the Gongila Formation revealed that the formation solely formed in a passive continental margin. Provenance evaluation indicated that the sediments were sourced from intermediate igneous rocks with few felsic and mafic materials in a generally granite province. This setting is generally characterized by moderate weathering, but pulses of intense conditions are also common. The Turonian of the Bornu Basin is dominantly defined by arid to semi- arid climatic condition superposed with relatively few periods of pronounced tropical to subtropical climate.

\section{References}

[1] Cullers, R.L., 2002. Implications of elemental concentrations for provenance, redox conditions, and metamorphic studies of shales and limestones near Pueblo, CO, USA: Chemical Geology, 191, 305-327.

[2] Spalletti, L.A., Limarino, C.O., Pinol, F.C., 2012. Petrology and geochemistry of Carboniferous siliciclastics from the Argentine Frontal Cordillera: A test of methods for interpreting provenance and tectonic Setting: Journal of South America Earth Science, 36, 32-54.

[3] DaPeng, L., YueLong, C., Zhong, W., Yu, L., Jian, Z., 2012, Paleozoic sedimentary record of the Xing-Meng Orogenic Belt, Inner Mongolia: implications for the provenances and tectonic evolution of the Central Asian Orogenic Belt: Chinese Science Bulletin, 57, 776-785. 
[4] Fu, X., Wang, J., Zeng, Y., Tan, F. and Feng, X., 2010. REE geochemistry of marine oil shale from the Changshe Mountain area, northern Tibet, China: International Journal of Coal Geology, 81, 191-199.

[5] Etemad-Saeed, N., Hosseini-Barzi, M., Armstrong-Altrin, J.S., 2011. Petrography and geochemistry of clastic sedimentary rocks as evidence for provenance of the Lower Cambrian Lalun Formation, Posht-ebadam block, Central Iran: Journal of African Earth Sciences, 61, 142159.

[6] Deconinck, J.F., Amedro, F., Baudin, F., Godet, A., Pellenard, P., Robaszynski, F., Zimmerlin, I., 2005. Late Cretaceous palaeoenvironments expressed by the clay mineralogy of Cenomanian Campanian chalks from the east of the Paris Basin: Cretaceous Research, 26, 171-179.

[7] Dera, G., Pellenard, P., Neige, P., Deconinck, J.F., Pucéat, E., Dommergues, J.L., 2009. Distribution of clay minerals in Early Jurassic Peritethyan seas: palaeoclimatic significance inferred from multiproxy comparisons: Palaeogeography Palaeoclimatology Palaeoecology, 271, 39-51.

[8] Carter, J. D., Barber, W., Tait, E.A and Jones, G.P. (1963). The geology of parts of Adamawa, Bauchi and Borno provinces in north-eastern Nigeria. Bulletin Geological Survey Nigeria. 30, 199.

[9] Shettima, B. Adams, F.D. and Joseph, M.V., 2017. Mineralogy and geochemistry of mudstones of the Bama Ridge (Upper Chad Formation) Bornu Basin, North-Eastern Nigeria, International Research Journal of Advanced Engineering and Science, Volume 2, Issue 1, 153 - 159

[10] Burke, K. C. (1976). The Chad basin: an active intra-continental basin. Tectonophysics, 36: 197 205.

[11] Nwajide, C.S., 2013. Geology of Nigeria's sedimentary basins. CCS Bookshop Ltd, Lagos, 86p.

[12] Guiraud, M., 1990. Tectono-sedimenatry framework of the early Cretaceous continental Bima Formation (Upper Benue Trough N.E. Nigeria). J. Afr. Earth Sci. 10, 341-353.

[13] Shettima, B., Abubakar, M.B., Kuku, A. and Haruna, A.I., 2018, Facies Analysis, Depositional Environments and Paleoclimate of the Cretaceous Bima Formation in the Gongola Sub - Basin, Northern Benue Trough, NE Nigeria. Journal of African Earth Sciences, 137, 193-207.

[14] Popoff, M., Wiedmann, J. and De Klazz, I., 1986. The Upper Cretaceous Gongila and Pindiga Formations, Northeastern Nigeria.Subdivisions, age stratigraphic correlations and paleogeographic implications. Ecologea Geol. Helv.,79, 343-363.

[15] Dike, E.F.C. (2002). Sedimentation and tectonic evolution of the Upper Benue Trough and Bornu Basin, Northeastern Nigeria. Nigerian Mining Geosciences Society 38th Annual and International Conference, Port Harcourt 2002 (NMGS/ELF award wining paper) Abstr. Vol., 45p

[16] Shettima, B, Kyari, A.M., Goni H. and Usman, L.A., 2009.. Facies and facies Architecture, Provenance and depositional environment of the Bama-Maiduguri Ridge Complex, Bornu Basin, northeastern Nigeria. 45th Nigerian Mining and Geosciences Society (NMGS) Annual International Conference Owerri, Abstract Vol, 54p.

[17] Condie, K.C., Boryta, M.D., Liu, J. and Quian, X., 1992. The origin of khondalites: geochemical evidence from the Archean to Early Proterozoic granulitic belt in the North China Craton: Precambrian Research, 59(3-4), 207-223.

[18] Cox, R., Lowe, D.R., Cullers, R.L., 1995. The influence of sediment recycling and basement composition on evolution of mudrock chemistry in the southwestern United States: Geochimica et Cosmochimica Acta, 59, 2919-2940.

[19] Bhatia, M.R. 1983. Plate Tectonics and Geochemical Composition of Sandstones. Journal of Geology, 91, 611-627.

[20] Bhatia M.R. and Crook K.A.W. 1986. Trace elements characteristics of graywackes and tectonic setting discrimination of sedimentary basins. Contrib. Mineral, Petrol., 92, 181-193.

[21] Roser, B.P. and Korsch, R.J., 1986. Determination of Tectonic Settings of Sandstone-Mudstone Suits Using SiO2 Content and K2O/Na2O Ratio. Journal of Geology, 94, 635-650. 
[22] Zaborski, P., Ugodulunwa, F., Idornigie, A., Nnabo, P. and Ibe, K. 1997. Stratigraphy and Structure of the Cretaceous Gongola Basin, Northeastern Nigeria. Bulletin Centre Research Production Elf Aquitaine, 22, 153-185.

[23] Roser, B.P. and Korsch, R.J., 1988. Provenance signatures of sandstone-mudstone suites determined using discriminant function analysis of major element data: Chemical Geology, 67, 119-139.

[24] Nesbitt, H.W. and Young, G.M., 1982. Early Proterozoic climates and plate motions inferred from major element chemistry of lutites: Nature, 299, 715-717.

[25] Wronkiewicz, D.J. and Condie, K.C., 1987. Geochemistry of Archean shales from the Witwatersrand Supergroup, South Africa: source-area weathering and provenance: Geochimica

[26] Fedo, C.M., Nesbitt, H.W. and Young, G.M., 1995. Unraveling the effects of potassium metasomatism in sedimentary rocks and paleosoils, with implications for paleoweathering conditions and provenance: Geology, 23, 921-924.

[27] Harnois, L., 1988. The CIW Index: A New Chemical Index of Weathering. Sedimentary Geology, 55, 319-322.et Cosmochimica Acta, 51, 2401-2416.

[28] Gallet, S., Jahn, B., Lanoë, B.V.V., Dia, A. and Rossello, E., 1998. Loess geochemistry and its implications for particle origin and composition of the upper continental crust: Earth and Planetary Science Letters, 156, 157-172.

[29] Újvári, G., Varga, A. and Balogh-Brunstad, Z.S., 2008, Origin, weathering, and geochemical composition of loess in southwestern Hungary: Quaternary Research, 69, 421-437.

[30] Fadipe, O.A., Carey, P.F., Akinlua, A. and Adekola, S.A., 2011. Provenance, diagenesis and reservoir quality of the Lower Cretaceous sandstone of the Orange Basin, South Africa: South African Journal of Geology, 114, 433-448.

[31] Srivastava, A.K., Randive, K.R. and Khare, N., 2013. Mineralogical and geochemical studies of glacial sediments from Schirmacher Oasis, East Antarctica: Quaternary International, 292, 205216.

[32] Gromet, L.P., Dymek, R.F., Haskin, L.A. and Korotev, R.L., 1984. The "North American Shale Composite": Its Compilation, Major and Trace Element Characteristics. Geochimica et Cosmochimica Acta , 48, 2469-2482.

[33] Taylor, S.R. and McLennan, S.M., 1985. The Continental Crust: its Composition and Evolution: Oxford, Blackwell, 349 pp.

[34] Westermann, S., Duchamp-Alphonse, S., Fiet, N., Fleitmann, D., Matera, V., Adatte, T. and Follmi, K.B., 2013, Paleoenvironmental changes during the Valanginian: New insights from variations in phosphorous contents and bulk-and clay mineralogies in the western Tethys: Paleogeography Paleoclimatology Paleoecology, 392, 196-208

[35] Chamley, H., 1989, Clay Sedimentology: Springer Verlag, Berlin Heidelberg New York, 623 pp.0

[36] Kübler, B., Jaboyedoff, M., 2000. Illite Cristallinity: Comptes Rendus de l'Académie des Sciences, Paris, 331, 75-89.

[37] McLennan, S.M., 1993. Weathering and global denudation: The Journal of Geology, 101, 295-303.

[38] Godet, A., Bodin, S., Adatte, T. and Föllmi, K., 2008, Platform-induced clay-mineral fractionation along northern Tethyan basin-platform transect: implications for the interpretation of Early Cretaceous climate change (Late Hauterivian-Early Aptian): Cretaceous Research, 29, 830-847.

[39] Duchamp-Alphonse, S., Fiet, N., Adatte, T., Pagel, M., 2011. Climate and sea-level variations long the northwestern Tethyan margin during the Valanginian $\mathrm{C}$-isotope excursion: mineralogical evidence from the Vocontian Basin (SE France): Palaeogeography Palaeoclimatology Palaeoecology, 302, 243-254.

[40] Weaver, C.E., 1989. Clays, Muds, and Shales: Amsterdam, Elsevier, 819 pp.

[41] Fürsich, F.T., Singh, I.B., Joachimski, M., Krumm, S., Schlirf, M. and Schlirf, S., 2005. Palaeoclimate reconstructions of the Middle Jurassic of Kachchh (western India): an integrated approach based on palaeoecological, oxygen isotopic, and clay mineralogical data: Palaeogeography Palaeoclimatology Palaeoecology, 217, 289-309. 
[42] Ruffell, A.H., McKinley, J.M. and Worden, R.H., 2002. Comparison of clay mineral stratigraphy to other proxy palaeoclimate indicators in the Mesozoic of NW Europe: Philosophical Transactions of the Royal Society, 360, 675-693.

[43] Tardy, Y., 1993. Petrologie des Laterite et des Sols Tropicaux. Paris, Masson, 143p.

[44] Raucsik, B. and Varga, A., 2008. Climate-environmental controls on clay mineralogy of the Hettangian-Bajocian successions of the Mecsek Mountains, Hungary: An evidence for extreme continental weathering during the early Toarcian oceanic anoxic event: Palaeogeography Palaeoclimatology Palaeoecology, 265, 1-13.

*Corresponding author.

E-mail address: bukarmohammed2@yahoo.com 